\title{
Strengthening Impaired-Driving Enforcement in the United States
}

\author{
Robert B. Voas and James C. Fell \\ Impaired Driving Center, Pacific Institute for Research and Evaluation, Calverton, MD
}

\section{Abstract}

Objective-Progress in reducing alcohol-impaired driving crash fatalities in the United States has stagnated over the last 15 years. This paper reviews two current U.S. driving-while-intoxicated (DWI) laws and their enforcement with an aim toward generating opportunities to improve their enforcement approaches.

Methods-Impaired-driving enforcement methods in Europe and Australia are compared with those in the United States, and the legal basis for current DWI criminal procedures is examined.

Results-An examination of relevant U.S. Supreme Court decisions and current legal practices indicates that the requirements for use of breath-test technology to determine blood alcohol concentrations of drivers on public roads are not entirely clear. Several potential methods for using field breath-test technology to improve the detection of impaired drivers are suggested. These include (a) breath testing all drivers stopped for certain violations that have a high probability of involving an impaired driver, (b) breath testing all drivers at sobriety checkpoints, and (c) breath testing all drivers involved in fatal and serious injury crashes.

Conclusions-Breath-test technology has enabled other countries around the world to adopt and implement enforcement strategies that serve as both general and specific deterrents to alcoholimpaired driving. Many of these enforcement strategies have been shown to be effective. If any one of these strategies can be adopted in the United States, further progress in reducing impaired driving is probable. It may be necessary to provide the U.S. Supreme Court with a test case of breath testing all drivers at a sobriety checkpoint, depending upon whether or not a police agency is willing to use that strategy.

\section{Keywords}

Impaired Driving; Blood Alcohol Concentration (BAC); Breath-Test Technology; Per Se Laws; Enforcement Procedures; U.S. Supreme Court Decisions

\section{INTRODUCTION}

\section{The Problem}

Motor-vehicle crashes are the leading cause of death for Americans age 4 and ages 11 through 27 (Subramanian 2012). In the United States, alcohol-impaired driving was involved in $31 \%$ of fatal crashes in 2010 and resulted in more than 10,000 deaths (National Center for Statistics and Analysis [NCSA] 2012a). Alcohol-related crashes cost the U.S. society an estimated $\$ 129$ billion in 2006 (Zaloshnja and Miller 2009). A national roadside survey of nighttime weekend drivers in 2007 indicated that $2 \%$ of the drivers on the roads 
have illegal blood alcohol concentrations (BACs) (Lacey et al. 2009). Zador, Krawchuk, and Moore (2000) estimated that only 1 of 88 drivers with illegal BACs is arrested for driving while intoxicated (DWI), whereas Beitel, Sharp, and Glauz (2000) estimated 1 in 200 using a different method. No comparable probabilities could be found for other countries around the world. A national telephone survey of more than 10,000 drivers showed that U.S. drivers admitted to 85.5 million drinking-and-driving trips in the past 30 days during 2008 (Moulton et al. 2010). Although the United States made progress in reducing impaired driving between 1982 and 1997, little has been achieved since that time (Dang 2008; Fell et al. 2009).

\section{Background}

A recent report from an expert committee established by the National Research Council (NRC) to compare highway safety programs in high-income "benchmark" nations to those in the United States (NRC, 2010) concluded that "the gap between traffic safety progress in the United States and other high-income countries deserves the attention of transportation administrators and the public because it indicates that the United States may be missing important opportunities to reduce traffic deaths and injuries. (page 9)" One area where the United States may be missing an opportunity, which is now a common practice in other nations, is the use of sobriety checkpoints with field breath tests in the enforcement of impaired-driving laws. As the NRC report notes, the United States has made little progress in reducing traffic fatalities since the mid-1990s (excluding the recent U.S. recession years of 2008 and 2009). This has been particularly true for impaired-driving-related fatalities because the percentage of all fatal crashes involving an impaired driver has not changed from 1997 to 2008 . When the recession in 2008 and 2009 reduced total fatalities by $9.3 \%$ and $9.7 \%$ (NCSA 2011), respectively, the percentage that involved an impaired driver actually increased slightly (NCSA 2010). The lack of progress in reducing impaired-drivingrelated fatal crashes (see Figure 1) has resulted in calls by both citizen activist organizations, such as Mothers Against Drunk Driving (MADD 2006), and researchers (e.g., Robertson et al. 2009) for increased attention to the impaired-driving problem and increased expenditures on impaired-driving enforcement. Although great progress was made between 1982 and 1997, Figure 1 shows that since 1997, the proportion of drivers involved in fatal crashes who were intoxicated has remained at 20 to $22 \%$. MADD is currently supporting legislation calling for mandatory alcohol ignition interlock devices for all offenders convicted of DWI. It remains to be seen how many states adopt such legislation and whether it will have a general deterrent effect similar to what per se and administrative license revocation (ALR) laws provided (Wagenaar et al. 2007, Wagenaar and Maldonado-Molina 2007). Unfortunately, both the ability to focus public attention on impaired driving and the capability to increase funding for DWI enforcement is limited by the current U.S. recession and the growing concern with terrorism. This suggests the importance of finding methods to improve the effectiveness of current laws and policies without requiring additional funding for DWI enforcement and adjudication. This study examines the gap described by the NRC (2010) between impaired-driving enforcement policies in the United States and other similar industrialized nations. The objective is to improve the effectiveness of current U.S. enforcement programs without broad new legislation or substantial increases in funding.

\section{METHODS}

Procedures for stopping and arresting drivers for DWI in the U.S. and other countries were examined. Two key elements in the impaired-driving enforcement process are:

- the policies for stopping vehicles to check for impaired drivers, and

- the procedures for breath-testing drivers to determine their BACs. 
Currently, apprehension of impaired drivers in the United States proceeds in three steps (see Table 1 that compares the U.S. process with Australia, Sweden, and Great Britain):

1. a vehicle in the traffic flow is selected for investigation;

2. the driver is interviewed and, if impairment is suspected, that driver may be required to perform sobriety tests; and

3. if there is probable cause to believe the driver is impaired, the driver is arrested and transported to the police station for evidential testing and booking.

When the first impaired-driving laws were adopted early in the $20^{\text {th }}$ century, the initial enforcement procedures required police officers to observe the driver's behavior and present sufficient evidence in court to support the ambiguous definition of "intoxicated driving." During that period, DWI laws in European nations typically required that the suspect be examined by a physician (National Safety Council 1976).

In Sweden in the 1920s and 1930s, Widmark (1932) published a series of articles that described the relationship of alcohol consumption to BACs. This led to the development of highly accurate blood and urine alcohol test procedures for use in the third phase of the apprehension process in the police station (Jones 2000). Initially, these tests were used only as corroborating evidence to augment the officer's or the physician's testimony. In 1936, however, Norway became the first nation to enact a per se law establishing a BAC of .05 grams per deciliter $(\mathrm{g} / \mathrm{dL})$ as an offense for drivers. This per se law provided authority to sanction drivers for DWI based upon the result of the BAC test—no other evidence (e.g., behavioral, field tests) was needed. If a driver was over the illegal BAC limit $(.05 \mathrm{~g} / \mathrm{dL}$ in this instance), that driver was guilty per se of DWI and appropriate sanctions were administered. Over time, most European nations have followed Norway's lead (Jones 2000). The United States was slow to adopt BAC per se laws. By the time the National Highway Traffic Safety Administration (NHTSA; Federal Register 1972, par. 242.6) recommended such laws in 1972, only two states had actually adopted BAC per se laws. However, all 50 states and the District of Columbia have such laws today set at $.08 \mathrm{~g} / \mathrm{dL}$ as the illegal limit (Mercer et al. 2010; U.S. Congress, Transportation Appropriations Bill, Section 342, signed by President Clinton on October 23, 2000). A BAC per se law potentially streamlines the apprehension and prosecution of impaired drivers, as in concept at least, it is based on only two findings: the accused was in charge of the vehicle (was the driver) and had a BAC at or higher than the illegal limit. If both findings are proven, the driver is guilty, per se, of DWI.

Borkenstein's invention of the breathalyzer provided a low-intrusion device for measuring BAC that officers could operate accurately in the police station (Borkenstein and Smith 1961). This new technology avoided the need to take offenders to a hospital or phlebotomist and wait for laboratory results of the blood analysis. This stimulated the passage of per se laws in the United States. In the late 1960s, progress in breath-testing technology led to the development of field BAC breath-test devices. Early handheld devices that the police could use at the roadside were crude; they required the suspect to inflate a balloon through a tube of reagent that changed color on contact with ethanol (Dubowski 1974; Jones 2000; Voas 1988). These crude devices were superseded by the development of handheld electronic sensors based on fuel cell technology in the early 1970s (Jones 2000). This provided the police with a method for rapidly conducting accurate BAC tests at the roadside in step 2 of the apprehension process, rather than having to wait until the suspect had been transported to the police station for step 3 processing (Table 1).

\section{Application of Field Breath Tests under BAC Per se Laws in Sweden and Australia}

In Sweden and Australia, the availability of portable field breath-test devices encouraged the use of random stop and test procedures. Sweden instituted a checkpoint procedure that 
empowered police to establish roadblocks at which all cars, or a random selection of cars, could be stopped and their drivers interviewed and breath tested (Ross 1984). Australia extended this random breath-test (RBT) enforcement technique to its logical limit by providing police with the authority to stop any vehicle at any time and demand a breath test. An over-the-limit BAC result immediately led to arrest and a second evidential test at the police station. Test refusal was criminalized and carried the same sanctions as a conviction for impaired driving (Homel 1990, 1993). Because any vehicle could be stopped at any time, this RBT procedure essentially moved breath testing to the front end of the apprehension process. Thus, RBT represents a full actuation of the BAC per se concept in the enforcement of impaired driving because only the two fundamental findings of the BAC per se law (being in charge of the vehicle and having a BAC greater than or equal to the limit) are involved in apprehension under the impaired-driving system (see Table 1). This can be characterized as a "chemistry-based" enforcement system (Voas and Lacey 1990). The RBT procedure became the principal method of impaired-driving enforcement in Australia, with some provinces testing a number of drivers each year equal to the total number of licensed drivers in the province (Homel 1993).

\section{The American Experience with Checkpoints}

In 1967, when the U.S. Department of Transportation was established, there was a limited tradition in some states of conducting checkpoints to verify that drivers had valid licenses. Strengthened by the Swedish example, this tradition was used as a foundation for the first national DWI enforcement program in 1969, which was conducted by the newly formed National Highway Safety Bureau, the predecessor to today's NHTSA. In that program, 35 Alcohol Safety Action Projects (ASAPs) were implemented in communities across the United States (Levy et al. 1977). Although more than one enforcement procedure was used in those projects, sobriety checkpoints were emphasized. The success of this strategy throughout the years has resulted in checkpoints becoming one of NHTSA's primary recommended DWI enforcement procedures (Compton 1983; NHTSA 1990, 1993, 1999 , 2000).

In the United States, however, sobriety checkpoints are quite different from those in Sweden or the RBT programs in Australia because handheld preliminary breath testers (PBTs), the central feature of checkpoints outside the United States, are not often used. Rather, at checkpoints in the United States, police engage in brief interviews with the motorist in an effort to identify impaired drivers. Although officers are trained to detect alcohol impairment, the interview time provided at checkpoints is too short to permit high accuracy of detection in identifying high-BAC drivers (Fell et al. 2004). This interview procedure has been shown to be significantly less efficient than using breath tests. It results in half of the over-the-BAC-limit drivers passing through the checkpoint undetected (Ferguson et al. 1995).

Henstridge, Homel, and Mackay (1997), in a time-series analysis of data from four Australian states, found that RBT was twice as effective as selective checkpoints. Sherman (1990) found that in Queensland, Australia, the RBT program resulted in a 35\% reduction in fatal crashes compared to a $15 \%$ reduction due to selective checkpoints. Sherman (1990) estimated that every increase of 1,000 drivers in the daily RBT rate corresponded to a decline of $6 \%$ in all serious crashes and 19\% in single-vehicle nighttime crashes. Peek-Asa (1999) and Shults et al. (2001) found small differences in RBT's influence on crashes in Australia versus the effectiveness of sobriety checkpoints in the United States. However, in a review by Solomon et al. (2011), RBT in Australia and Europe was deemed substantially more effective than sobriety checkpoints as they are now conducted in Canada and the United States. Lund and Jones (1987) noted, however, that the efficiency of U.S. 
checkpoints could be increased when a passive alcohol sensing device was used on all motorists passing through a checkpoint (see later discussion of passive alcohol sensors).

The limited use of field breath testers in the U.S. law enforcement system stems from the current interpretation of the Fourth Amendment to the U.S. Constitution, which prohibits unreasonable searches and seizures (meaning without individualized suspicion).

Checkpoints involve both a seizure (stopping the car) and a search (breath testing if a field breath sensor is used). U.S. courts have concluded that random stopping of a vehicle is an unreasonable "seizure" under the Fourth Amendment (Delaware v. Prouse, 440 U.S. 648, 1979). However, an exception was made for stops in special "sobriety checkpoint" operations if they met specific conditions established by the U.S. Supreme Court based on a balancing test (Michigan Dept. of State Police v. Sitz, 496 U.S. 444, 1990; hereinafter referred to as "Michigan v. Sitz"). The balancing test considered the need for the state to protect the public weighed against the small intrusion involved in stopping a driver for a brief interview.

\section{The Use of Preliminary Breath Tests at Checkpoints}

Unfortunately, the other key element of the sobriety checkpoint procedure-the use of a field breath-test device (a "search")—-was not used to detect the drinking of all drivers stopped at the checkpoint in the U.S. Supreme Court Sitz case. Rather, the officers were required to detect impaired motorists though the observations they could make during a brief interview, which averaged 25 seconds (Sitz, 1990). Thus, the decision did not specifically deal with breath testing. However, Chief Justice Rehnquist, delivering the majority opinion, concluded that:

Experts in police science might disagree over which of several methods of apprehending drunken drivers is preferable as an ideal. But for purposes of Fourth Amendment analysis, the choice among such reasonable alternatives remains with the government officials who have a unique understanding of and responsibility for, limited public resources, including a finite number of police officers. (Sitz, 496 U.S. at 453-454)

This appeared to provide discretion for police departments to require a breath test of all drivers stopped at checkpoints. However, the decision was based on balancing the state's interest in preventing drunk driving against the degree of intrusion upon the motorist in which the degree of intrusion was judged to be "slight" (Sitz, 496 U.S. at 451). Whether the PBT test would be a "slight" intrusion was not considered. The absence of a mandatory breath test for all motorists in the Sitz case leaves the issue unresolved as to whether such a requirement at a checkpoint would increase the level of intrusion sufficiently to tip the balance in favor of motorist privacy concerns. The statement in the Rehnquist opinion, that detection methods should be left to the discretion of police experts, appears to invite police agencies to create a test case for this issue by breath testing all motorists stopped at sobriety checkpoints.

To date, the requisite case has not occurred, so in most jurisdictions, all drivers are not required to provide a preliminary breath test at the beginning of the apprehension process as they would be in Sweden or Australia or in 44 other countries around the world (Solomon et al. 2011). It will likely take substantial persuasive powers to convince a police agency (or agencies) to breath test every driver at a checkpoint. It could result in a public backlash that most agencies want to avoid. However, if the local community is educated on the balance between the need to protect the public and the small intrusion of breath testing at a sobriety checkpoint, and they buy into it, that public support could influence police action. 
In the United States, however, PBTs may be used in some locations if the officer has reason to believe the driver is impaired. Generally, this occurs after completion of the behavioral SFSTs to confirm the officer's judgment that the suspect is over the BAC limit.

\section{RESULTS}

\section{Efforts to Overcome Opposition to Preliminary Breath Tests and Sobriety Checkpoints}

In an effort to overcome the current limitations on preliminary breath testing by making the test less intrusive, a fuel-cell passive alcohol sensor (PAS) was developed over two decades ago that, when held 4 to 6 inches in front of the suspect's face, can detect with reasonable accuracy the alcohol in the expired air of drivers who have been drinking (Voas et al. 2006). Evaluations of the use of PAS devices have demonstrated that, without the PAS units, police officers miss up to half of the drivers who are over the BAC limit when passing through checkpoints (Ferguson et al. 1995). The use of PAS devices, which are typically built into the officers' flashlights, has been shown to identify half of those over-the-limit drivers who currently escape detection at checkpoints (see Table 2), while decreasing the number of drivers unnecessarily detained at checkpoints because of ambiguous initial screening (Ferguson et al. 1995; Wells et al. 1996). Despite this evidence for their effectiveness, it has been difficult to persuade officers to use PAS devices at checkpoints (Fell et al. 2008; Voas et al. 2005). The reasons for this are not entirely clear, but apparently, officers find them awkward to handle and are not fully convinced that, given their own ability to detect impaired drivers, the PAS devices are needed.

Furthermore, despite the evidence that checkpoints are the method of choice for highvisibility enforcement (Elder et al. 2002), many police departments currently resist the use of checkpoints. There are apparently two primary reasons: the belief that sobriety checkpoints require a substantial number of officers (and therefore are expensive), and checkpoints result in few arrests (and therefore appear ineffective) (Fell et al. 2004). Research has identified two procedures-low-staff checkpoints and PAS devices-that deal with those issues. Studies have shown that sobriety checkpoints conducted by relatively few officers are as effective in reducing alcohol-related crashes as those involving large groups of officers (Lacey et al. 2006; Stuster and Blowers 1995), and the use of PAS devices results in apprehension rates per officer hour as high as those in traditional dedicated patrol operations (Voas 2008). These two concepts have been combined in a "PASpoint Enforcement System" that can be integrated with typical police patrol operations without employing officers on overtime (Voas et al. 2005). This procedure will permit conducting of checkpoints regularly by medium- to small-sized police departments. However, this system remains to be widely demonstrated and adopted by police departments, although the Fresno, California, Police Department has expressed a willingness to test the PASpoint concept over a 1-year period.

\section{Current Administrative Search Programs}

A new factor since the U.S. Supreme Court established the constitutional basis for sobriety checkpoints is homeland security, under which the public has come to expect highly enhanced security procedures: (1) going through magnetic detectors and having purses and brief cases inspected in order to enter government buildings; and (2) under the 2001 Aviation and Transportation Security Act (Aviation and Transportation Security Act, S. 1447-107th Congress, Pub.L. 107-71; 2001), having luggage, shoes, and coats X-rayed, and going through body scanners and pat-downs at airports. The concern for transportation safety and security has also justified legislation requiring random testing of employees in travel-related industries (Brady et al. 2009). This new security environment has reduced the public expectation of privacy and presumably increased the public's acceptance of intrusive 
searches compared to the period when the Supreme Court handed down its opinion on Sitz. The current acceptance of the intrusive air travel screening is based on the tragic events of September 11, 2001 (9/11), in which almost 3,000 people died (2,752 at the World Trade Center, 184 at the Pentagon, and 45 in the airplane that crashed in Pennsylvania). Since that time, no terrorism deaths have occurred on U.S. airlines. Much less understood nor communicated to the public is the fact that impaired driving has resulted in 3,000 deaths every 3 months annually on average since 9/11. In a recent national poll of U.S. drivers, $87 \%$ said that people driving after drinking alcohol was a very serious threat to their personal safety, and $98 \%$ said that they personally considered drinking and driving as unacceptable (AAA Foundation for Traffic Safety 2010). Therefore, a better understanding by the public of the extent of the losses caused by alcohol-impaired drivers should result in stronger support for impaired-driving laws, similar to the support being given to airline and homeland security. Because the key basis for the Sitz decision was a balancing test of the need for the state to protect the public versus the extent of the intrusion on the individual driver, the public's view and the Supreme Court's evaluation of the extent of the intrusion involved in a field breath test should be lower in the current context.

Justice Alito's 2007 opinion, while serving on the $9^{\text {th }}$ Circuit Court of Appeals, upholding airport checkpoints is an indication that the current U.S. Supreme Court might accept BAC breath tests at roadside checkpoints. An interesting statement in his opinion is that searches are reasonable if they escalate invasiveness after a lower level of screening discloses a reason to conduct a more probing search (Rosen 2010). This raises the issue of the relative intrusiveness of the BAC breath test versus standardized field sobriety tests (SFSTs). Administering a PBT requires 30 seconds or less and can be conducted in the privacy of the suspect's car, whereas the SFSTs require 10 to 20 minutes and are conducted on the roadside usually in full view of the public. . It could be argued that, the first action of an officer who has a suspicion that a driver is impaired should be the less intrusive PBT test, then moving on to the SFSTs only after having obtained an indication from a PBT that the suspect is over the BAC limit. Currently, this more efficient procedure is not being used because of concern that the officer will overlook the possibility of drug impairment, but the absence of an indication that alcohol is accounting for the driver's behavior should immediately alert the officer to the possibility of drug impairment.

The importance of the public's reaction to being stopped was recognized in the dissent to Sitz written by Justice Stevens with concurrence by Justices Brennan and Marshall. The primary focus of the dissent was based on the intrusion produced by surprise when unexpectedly confronted by a sobriety checkpoint. The dissent distinguished between mobile checkpoints that "...depend upon surprise..." and ".... a host of other investigatory procedures...," including stationary checkpoints that do not depend on surprise. The dissent notes the "...common practice to require every prospective airline passenger or every visitor to a public building to pass through a metal detector..." (Sitz, 496 U.S. at 473) and includes the suggestion that "... a state could condition access to its toll roads upon not only paying a toll but also taking a uniformly administered breathalyzer test" (Sitz, 496 U.S. at 474). This position appears to minimize the concern over BAC breath testing in relation to the significance of the conditions of the vehicle stop (seizure).

\section{Use of Field Breath Tests in Traditional Impaired-Driving Enforcement}

The movement of the biological testing from the police station or hospital to the roadside in the second half of the 20th century was dubbed the "Scandinavian System" by Ross (1975) because of its origin in Sweden. It was adopted in modified form by most industrialized nations. The Netherlands, France (Ross 1984), and Australia (Homel 1990, 1993, 1994) emulated the Swedish checkpoint system; other countries provided for breath-testing devices for officers to use in their traditional enforcement operations not related to checkpoint stops. 
Britain initiated an innovative procedure in the Road Safety Act of 1967 (Ross 1973). That legislation provided British police with the authority to require a breath test of any driver they stopped if any one or more of three conditions was met: (1) the officer had reason to believe that the driver was impaired, (2) the driver was involved in a crash, or (3) the driver was guilty of committing another traffic offense. When implemented, the British Road Safety Act had a dramatic effect, not only markedly reducing alcohol-related crashes, but also reducing non-alcohol-related crashes apparently by persuading even sober drivers to exert greater care when driving to avoid the possibility of being breath tested for BAC. Unfortunately, this success diminished because the additional resources required for implementation of this law, including police overtime and pay, led to the strategy being abandoned. It is very likely that the large number of moving violations cited by officers at traffic stops discouraged the continued implementation of the method. Tellingly, a short revival of the system by one sheriff produced a rapid drop in alcohol-related crashes, demonstrating anew that this approach could have continued to be effective (Ross 1977). Nevertheless, despite this demonstration, enforcement of the law was halted once again.

The British Road Safety Act points to some possible options for strengthening DWI enforcement in the United States. That law provided for BAC breath testing under three conditions: (1) the officer had reason to believe that the driver was impaired (current practice in the United States), (2) the driver committed a traffic offense, and (3) the driver was involved in a crash. The first condition-stopping based on the police officer's suspicion-is one already used in the United States. Stuster (1997) conducted research on the development of cues available to police officers on patrol that indicate the driver is impaired. The guide that resulted from the research is shown in Figure 2. On the left are the vehicle maneuvers that indicate the driver may be impaired; on the right are the driver behaviors that the officer can observe once the vehicle has been stopped. Note the relatively high probability values of a driver having a BAC $\geq .08 \mathrm{~g} / \mathrm{dL}$ associated with the vehicle maneuvers ranging from a probability of .35 to .90 . These have been accepted by the courts as sufficient cause for stopping (seizing) the vehicle under the Fourth Amendment.

Presumably, such signs provide the individualized suspicion required to perform a search (a BAC breath test) under the Fourth Amendment; however, PBTs are rarely used until standardized field sobriety tests are performed, which requires considerably more time.

\section{Testing Drivers Stopped and Cited for Traffic Violations}

The second provision of the British Road Safety Act provided that a BAC breath test could be required if the driver was guilty of a traffic law violation. This may have been overreaching, which contributed to the failure of the police to continue to enforce the law fully. Because there are so many opportunities to ticket drivers for relatively minor moving violations when, in most cases, there is no evidence of impairment, officers may have been reluctant to take the time to breath test drivers qualifying under the traffic violation provision.

Requiring a breath test for drivers cited for a moving traffic offense avoids the issue of random stopping, as it provides individualized suspicion that an offense has been committed. Though it seems unlikely that the U.S. public would support the testing of every driver receiving a traffic citation, there are offenses (e.g., reckless driving) that are a clear and serious threat to safety. These offenses are so far outside the limits of normal driving behavior that they suggest the possibility of alcohol impairment, which could make BAC breath testing reasonable and acceptable. Perhaps speeding 20 miles an hour over the speed limit and driving with a suspended license would also meet this criterion. Perhaps the four behaviors shown in Figure 2 would suffice. States could adopt legislation requiring a screening BAC breath test for such offenses as the traffic stops would be for cause and the behavior suggestive of intoxication. In this procedure, the driving behavior that justified the 
stop would also provide the basis for conducting a PBT at roadside, and an over-the-limit result would provide probable cause to make a DWI arrest and to require an evidential breath test.

\section{Testing Drivers in Crashes for BAC}

The final basis for field breath testing in the British Road Safety Act was involvement in a crash (Ross, 1973). Certainly, the fact that a third of all fatal crashes in the United States involve a driver at or higher than the $.08 \mathrm{BAC}$ illegal limit should clearly make it "reasonable" to require all drivers in such crashes to be tested. However, as the Fatality Analysis Reporting System (FARS) record demonstrates, the lack of a mandatory testing law has made this difficult to achieve (NCSA 2008). Because the rate of alcohol involvement is higher in serious injury and fatal crashes compared to property-damage-only crashes, it should be possible to establish public support for identifying involvement in a serious injury crash as a basis for further investigation. This investigation would include a mandatory PBT screening test that, if over the BAC limit, provides probable cause for an arrest and an evidential test. Currently, the BAC testing rate for drivers killed in crashes is $71 \%$, but only $30 \%$ of surviving drivers in fatal crashes are tested for a BAC (NCSA 2012b). A recent NHTSA report recommends that police adopt a policy to test all surviving drivers involved in fatal crashes for a BAC (Casanova et al. 2012). The National Transportation Safety Board (NTSB) recently recommended that at a goal of at least $60 \%$ of surviving drivers in fatal crashes be tested for a BAC (NTSB 2012).

In sum, there are abundant and compelling opportunities for strengthening the DWI enforcement system in the United States if society accepts moving toward a more aggressive use of field alcohol screening. There are two limitations on the use of screening devices in the United States not encountered in similar countries abroad. First, the opportunities for the application of BAC breath testing are limited by requiring suspicion of impairment as a prerequisite for using PBTs. Second, states have not made either BAC screening-test refusal or an over-the-limit BAC test screening result sufficient evidence make an arrest and require an evidential breath test, as is common practice in other countries. This failure to take advantage of the PBT technology results in a failure to detect a significant number of overthe-limit drivers (Ferguson et al. 1995). Also, the reliance on the observation of impairment requires extensive field observations and extended paperwork by the police, often requiring 3 or more hours to make a DWI arrest, discourages officers from becoming involved in DWI enforcement (Simpson and Robertson 2001).

\section{Racial Profiling and BAC Per se Laws}

A key feature of BAC per se laws is that they define the offense in objective terms. Short of videotaping the field arrest activity, behavioral observations are necessarily somewhat subjective. This can open the arrest process to the possibility of bias in the judgments officers must make in apprehending an impaired driver. Much of the time, there are no witnesses to the interviews or the field sobriety tests of the offender. Often, the offender is in a weak position to challenge the officer's statements in court. Therefore, Justice Stevens, in his dissent from the Sitz decision expressed concern with the officer's discretion in examining an impaired-driving suspect:

A Michigan officer who questions a motorist at a sobriety checkpoint has virtually unlimited discretion to detain the driver on the basis of the slightest suspicion. A ruddy complexion, an unbuttoned shirt, bloodshot eyes, or a speech impediment may suffice to prolong the detention. Any driver who had just consumed a glass of beer, or even a sip of wine, would almost certainly have the burden of demonstrating to the officer that his or her driving ability was not impaired (Sitz, 496 U.S. at 464-465). 
The PBT can quickly (within 30 seconds) provide the officer with an objective, highly accurate indication of the true extent to which the motorist has been drinking. The PBT result could be the basis for inviting the driver out of the car for the SFSTs. That decision is important because the SFSTs are usually performed in public with the potential to cause considerable embarrassment to an innocent, unimpaired driver, as well as taking up the officer's time unnecessarily. Where breath measurement has been used at the front end of the checkpoint interviews, the number of DWI arrests has increased by $50 \%$, and the number of drivers unnecessarily detained for SFSTs has been reduced (Ferguson et al. 1995). A study by Zador et al. (2000) using arrest information and survey data indicated that police conduct about six DWI investigations for each DWI arrest they make. Using the PBT more aggressively would reduce the number of fruitless investigations for the officers, as well as reduce the number impaired drivers who escape detection and the extent of unnecessary intrusion on the public. A well-managed preliminary and evidential chemical test program can provide the best assurance for the driving public that the data used in the criminal justice system to prosecute impaired drivers are accurate and unbiased. However, in the current U.S. system, where conducting a preliminary breath test and an evidential test must be based upon suspicion of alcohol impairment and where both tests can be refused with minimal or no consequences, the detection of behavioral impairment by the officer becomes necessary (Simpson and Robertson 2001; Zwicker et al. 2005).

When field breath tests for BAC measures were first introduced, there was some speculation that many suspects would welcome a chemical test as a method of proving their innocence. But that was overshadowed by the strong advice coming from many defense attorneys to refuse the chemical test because an over-the-limit result would make avoiding conviction more difficult. Nevertheless, the PBT could be used in the case cited by Justice Stevens to shortcut the investigation and avoid subjection to the highly intrusive SFSTs. It could even impose on the officer the responsibility to offer the test before proceeding further in the investigation. This potential utility for the innocent driver is prevented, however, by the presence of the simultaneous historic criminal impaired-driving law, which allows the arrest of a driver with a low or zero BAC if there are signs of driving impairment. As noted, the policy in most jurisdictions is not to use the PBT at the beginning of an investigation to prevent officers from overly relying on the device and missing drug-impaired drivers. The tradeoff between missing the substantial number of impaired drivers whose tolerance to alcohol makes them difficult to detect with the SFSTs versus the number of drug-impaired drivers arrested based on their performance on the SFSTs has yet to be determined, but it raises the issue of the overall efficiency of current DWI apprehension policies.

\section{DISCUSSION}

Progress in reducing alcohol-impaired driving in the United States has stagnated. In 2006, $34 \%$ of fatally injured drivers in the United States had BACs $\geq .05 \mathrm{~g} / \mathrm{dL}$ compared to $29 \%$ in Australia (Watson 2010) and only 17\% in Sweden (Jones 2010) (see Figure 3).

Although the police in the United States are as well-equipped and well-trained for impaireddriving enforcement as any in the world, the United States has fallen behind other industrialized nations in the efficiency of enforcement operations. This is due to the failure to exploit fully the programs and technologies based on BAC per se laws. This failure can be traced to the lack of clarity in judicial decisions regarding the use of BAC-sensing technologies and resulting police policies that minimize the use of field breath-test devices. There is a need to examine current enforcement procedures and revisit legal precedents that govern the DWI criminal justice system. Current enforcement procedures in Sweden and Australia are not considered overly intrusive by the citizens of those countries and, in fact, are considered acceptable for public safety reasons. 
Several opportunities exist for clarifying the legal issues that are influencing current enforcement practices via carefully planned demonstration programs. Among them are:

1. requiring a preliminary breath test of all motorists stopped at a sobriety checkpoint;

2. requiring a preliminary breath test of all motorists stopped for exhibiting driving behaviors that have been shown to be indicative of driver impairment (see Figure 2); and

3. requiring a preliminary breath test of all motorists involved in a serious injury or fatal crash.

Testing the efficacy of these concepts in demonstration projects could clarify current laws and lead to enforcement policy changes that could be much more effective and efficient than those currently in practice. It is likely these strategies will pass the balancing test of minimal intrusion for the public safety interest if they are challenged. The main barrier is to persuade a police agency to test these concepts and be willing to accept the possible public backlash and court challenges. Developing public support for these strategies will be a key to successful implementation.

To achieve the needed strengthening of the DWI enforcement system in the United States, it will be necessary to harness the public's concern with the problem through an improved understanding of the risk that all road users face because of alcohol-impaired drivers. With better recognition of the emotional and societal costs of impaired driving to the nation, the public may demand greater protection from impaired drivers and support DWI enforcement programs that are more effective. Despite the clear evidence that alcohol-related crashes are a major source of death, injury, and societal costs, the United States has failed to take full advantage of established technologies for identifying drivers impaired by alcohol. If the U.S. DWI enforcement system remains almost completely dependent on demonstrating behavior impairment, it is unlikely to either increase the apprehension of impaired drivers or reduce the number of road users fatally injured by drivers with illegal BACs.

\section{Acknowledgments}

Funding for this article was provided partially through a grant from the National Institute on Alcohol Abuse and Alcoholism (NIAAA, Grant Numbers R01 AA018352 and P20 AA017831). The authors would like to thank the following individuals for their initial review of this article and the important comments and guidance they provided: Erika Chamberlain, Heidi Coleman, Richard Compton, Michael Greene, J.T. Griffin, Ralph Hingson, Andy Murie, Robert Solomon, Stephen Talpins, Alexander Wagenaar, and Michele Fields.

\section{References}

AAA Foundation for Traffic Safety. 2010 Traffic Safety Culture Index. Washington, DC: AAA Foundation for Traffic Safety; 2010.

Beitel GA, Sharp MC, Glauz WD. Probability of arrest while driving under the influence of alcohol. Inj Prev. 2000; 6:158-161. [PubMed: 10875678]

Borkenstein RF, Smith HW. The breathalyzer and its application. Med Sci Law. 1961; 1:13.

Brady JE, Baker SP, DiMaggio C, McCarthy ML, Rebok GW, Li G. Effectiveness of mandatory alcohol testing programs in reducing alcohol involvement in fatal motor carrier crashes. Am J Epidemiol. 2009; 170:775-782. [PubMed: 19692328]

Casanova, T.; Hedlund, J.; Tison, J. State blood alcohol concentation (BAC) testing and reporting for drivers involved in fatal crashes: Current practices, results and strategies, 1997-2009. Washington, DC: U.S. Department of Transportation, National Highway Traffic Safety Administration; 2012. DOT HS 811661 
Compton, R. The use of safety checkpoints for DWI enforcement. Washington, DC: U.S. Department of Transportation, National Highway Traffic Safety Administration; 1983. DOT HS 806476. Available at: http://ntl.bts.gov/lib/25000/25700/25713/DOT-HS-806-476.pdf

Dang, JN. Statistical analysis of alcohol-related driving trends, 1982-2005. Washington, DC: National Highway Traffic Safety Administration; 2008. DOT HS 810 942. Available at: http://wwwnrd.nhtsa.dot.gov/Pubs/810942.pdf

Dubowski, KM. Recent developments in breath-alcohol analysis. In: Israelstam, S.; Lambert, S., editors. Alcohol Drugs and Traffic Safety, Proceedings of the Sixth Inermnational Conference on Alcohol, Drugs and Traffic Safety. Toronto, Canada: Addiction Research Foundation of Ontario; 1974. p. 483-494.

Elder RW, Shults RA, Sleet DA, Nichols JL, Zaza S, Thompson RS. Effectiveness of sobriety checkpoints for reducing alcohol-involved crashes. Traffic Inj Prev. 2002; 3:266-274.

Fell JC, Compton C, Voas RB. A note on the use of passive alcohol sensors during routine traffic stops. Traffic Inj Prev. 2008; 9:534-538. [PubMed: 19058099]

Fell JC, Lacey JH, Voas RB. Sobriety checkpoints: Evidence of effectiveness is strong, but use is limited. Traffic Inj Prev. 2004; 5:220-227. [PubMed: 15276922]

Fell JC, Tippetts AS, Voas RB. Fatal traffic crashes involving drinking drivers: What have we learned? Ann Adv Automot Med. 2009; 53:63-76. [PubMed: 20184833]

Ferguson SA, Wells JK, Lund AK. The role of passive alcohol sensors in detecting alcohol-impaired drivers at sobriety checkpoints. Alcohol, Drugs, and Driving. 1995; 11:23-30.

Henstridge, J.; Homel, R.; Mackay, P. The long-term effects of random breath testing in four Australian states: a time series analysis. Canberra, Australia: Federal Office of Road Safety; 1997. No. CR 162

Homel, R. Random breath testing and random stopping programs in Australia. In: Wilson, RJ.; Mann, RE., editors. Drinking and driving: Advances in research and prevention. New York: The Guilford Press; 1990. p. 159-202.

Homel R. Random breath testing in Australia: Getting it to work according to specifications. Addiction. 1993; 88:S27-S33.

Homel R. Drink-driving law enforcement and the legal blood alcohol limit in New South Wales. Accid Anal Prev. 1994; 26:147-155. [PubMed: 8198683]

Jones AW. Measuring alcohol in blood and breath for forensic purposes-A historical review. Forensic Sc Rev. 2000; 12:151-182.

Jones, AW. Occurrence of alcohol and other drugs in femoral blood samples from drivers killed in road-traffic crashes in Sweden. T2010 Conference; 22-26 August 2010; Oslo, Norway: International Conference on Alcohol, Drugs and Traffic Safety (ICADTS); 2010. Book of Abstracts

Lacey, J.; Kelley-Baker, T.; Furr-Holden, CDM., et al. 2007 National Roadside Survey of Alcohol and Drug Use by Drivers: Alcohol Results. Washington, DC: US Department of Transportation, National Highway Traffic Safety Administration. 2009. DOT HS 811 248. Available at: http:// www.nhtsa.gov/Driving+Safety/Research+\&+Evaluation/2007+National+Roadside+Survey+of + Alcohol+and+Drug+Use+by+Drivers

Lacey JH, Kelley-Baker T, Ferguson SA, Rider RP. Low-manpower checkpoints: Can they provide effective DUI enforcement for small communities? Traffic Inj Prev. 2006; 7:213-218. [PubMed: 16990234]

Levy P, Voas RB, Johnson P, Klein T. Evaluation of the ASAPs. J Saf Res. 1977; 10:162-176.

Lund, AF.; Jones, IS. Detection of impaired drivers with a passive alcohol sensor. In: Noordzij, PC.; Roszbach, R., editors. Alcohol, drugs and traffic safety 'T86. New York: Excerpta Medica; 1987. p. 379-382.

Mercer SL, Sleet DA, Elder RW, Cole KH, Shults RA, Nichols JL. Translating evidence into policy: Lessons learned from the case of lowering the legal blood alcohol limit for drivers. Ann Epidemiol. 2010; 20:412-420. [PubMed: 20470967]

Michigan Dept. of State Police v. Sitz, 496 U.S. 444, 1990.

Mothers Against Drunk Driving. Alcohol-related laws. Mothers Against Drunk Driving (MADD); 2006. Available at: http://www.madd.org/laws 
Moulton, BE.; Peterson, A.; Haddix, D.; Drew, L. National Survey of Drinking and Driving Attitudes and Behaviors: 2008 (Volume II: Findings Report). Washington, DC: U.S. Department of Transportation, National Highway Traffic Safety Administration; 2010. DOT HS 811343

National Center for Statistics \& Analysis. Traffic Safety Facts, 2010 Data: State alcohol-impaired driving estimates. Washington, DC: U.S. Department of Transportation, National Highway Traffic Safety Administration; 2012. DOT HS 811 612. Available at: http://www-nrd.nhtsa.dot.gov/Pubs/ 811612.pdf

National Center for Statistics and Analysis. Traffic Safety Facts: 2007 data: State alcohol-impaired driving estimates. Washington, DC: U.S. Department of Transportation, National Highway Traffic Safety Administration; 2008. Available at: http://www-nrd.nhtsa.dot.gov/Pubs/811167.pdf

National Center for Statistics and Analysis. Traffic Safety Facts: 2009 data. Washington, DC: U.S. Department of Transportation, National Highway Traffic Safety Administration; 2010. Alcoholimpaired driving. Available at: http://www-nrd.nhtsa.dot.gov/Pubs/811385.PDF

National Center for Statistics and Analysis. Traffic Safety Facts: Crash stats. Washington, DC: U.S. Department of Transportation, National Highway Traffic Safety Administratioin; 2011. Early estimate of motor vehicle fatalities in 2012. Available at: http://www-nrd.nhtsa.dot.gov/Pubs/ 811451.pdf

National Center for Statistics and Analysis. Traffic Safety Facts: 2010 data. Washington, DC: U.S. Department of Transportation, National Highway Traffic Safety Administration; 2012. Alcoholimpaired driving. Available at: http://www-nrd.nhtsa.dot.gov/Pubs/811606.pdf

National Highway Traffic Safety Administration. The use of sobriety checkpoints for impaired driving enforcement. Washington, DC: U.S. Department of Transportation, National Highway Traffic Safety Administration, Office of Enforcement and Emergency Services; 1990. DOT HS 807656. Available at: http://stopdruggeddriving.org/pdfs/SobrietyCheckpoints.pdf

National Highway Traffic Safety Administration. Sobriety checkpoints: Point/counterpoint. Washington, DC: U.S. Department of Transportation, National Highway Traffic Safety Administration; 1993. DOT HS 807916

National Highway Traffic Safety Administration. Law enforcement training video on sobriety checkpoints. Washington, DC: U.S. Department of Transportation, National Highway Traffic Safety Administration; 1999. DOT HS 808990

National Highway Traffic Safety Administration. Saturation patrols and sobriety checkpoints: A howto guide for planning and publicizing impaired driving enforcement efforts. Washington, DC: U.S. Department of Transportation, National Highway Traffic Safety Administration; 2000. DOT HS 809 063. Available at: http://www.nhtsa.gov/people/injury/alcohol/saturation_patrols/index.html

National Highway Traffic Safety Administration. Highway Safety Program Standards. Federal Register. 1972; 37:15602-15621.

National Highway Traffic Safety Administration. Fatality analysis reporting system data files, 1982-2010. Washington, DC: U.S. Department of Transportation, National Highway Traffic Safety Administration; 2012. Available at: ftp://ftp.nhtsa.dot.gov/fars/ [Accessed April 12, 2012]

National Research Council. Achieving Traffic Safety Goals in the United States: Lessons for Other Nations. Washington, DC: National Academy of Sciences; 2010. TRB Special Report 300

National Safety Council. Alcohol and the impaired driver. Chicago, IL: National Safety Council (NSC); 1976.

National Transportation Safety Board. Safety recommendation. Washington, DC: National Transportation Safety Board; 2012. H-12-32 and -33

Peek-Asa C. The effect of random alcohol screening in reducing motor vehicle crash injuries. Am J Prev Med. 1999; 16:57-67. [PubMed: 9921387]

Robertson, RD.; Holmes, E.; Simpson, H. Impaired Driving Priorities. Ottawa, Ontario, Canada: Traffic Injury Research Foundation; 2009. A criminal justice perspective.

Rosen, J. [Accessed April 12, 2010] Why the TSA pat-downs and body scans are unconstitutional [Opinions]. The Washington Post. 2010 Nov 28. Available at http://www.washingtonpost.com/wpdyn/content/article/2010/11/24/AR2010112404510.html

Ross HL. Law, science and accidents: The British Road Safety Act of 1967. J Legal Stud. 1973; 2:178.

Traffic Inj Prev. Author manuscript; available in PMC 2014 January 01. 
Ross HL. The Scandinavian myth: The effectiveness of drinking-and-driving legislation in Sweden and Norway. J Legal Stud. 1975; 4:285-310.

Ross HL. Deterrence regained: The Cheshire constabulary's breathalyzer blitz. J Legal Stud. 1977; 6:241-249.

Ross, HL. Deterring the drinking driver: Legal policy and social control. 2. Lexington, MA: Lexington Books; 1984.

Sherman, LW. Crime and Justice: An Annual Review of Research. Chicago: University of Chicago Press; 1990. Police crackdowns: Initial and residual deterrence.

Shults RA, Elder RW, Sleet DA, et al. Reviews of evidence regarding interventions to reduce alcoholimpaired driving. Am J Prev Med. 2001; 21:66-88. [PubMed: 11691562]

Simpson, HM.; Robertson, RD. Enforcement, DWI system improvements for dealing with hard core drinking drivers. Ottawa, Ontario, Canada: Traffic Injury Research Foundation; 2001. p. 17

Solomon R, Chamberlain E, Abdoullea M, Tinholt B. Random breath testing: A Canadian perspective. Traffic Inj Prev. 2011; 12:111-119. [PubMed: 21469017]

Stuster, JW. The detection of DWI at BACs below 0.10. Washington, DC: U.S. Department of Transportation, National Highway Traffic Safety Administration; 1997. Final Report. Available at: http://www.popcenter.org/problems/drunk_driving/PDFs/NHTSA_1997.pdf

Stuster, JW.; Blowers, MA. Experimental evaluation of sobriety checkpoint programs. Washington, DC: U.S. Department of Transportation, National Highway Safety Administration; 1995. DOT HS 808 287. Available at: http://ntl.bts.gov/lib/25000/25900/25932/DOT-HS-808-287.pdf

Subramanian, R. Traffic Safety Facts: Research Notes. Washington, DC: U.S. Department of Transportation, National Highway of Traffic Safety; 2012. Motor vehicle traffic crashes as a leading cause of death in the United States, 2008 and 2009. Available at: http://wwwnrd.nhtsa.dot.gov/Pubs/811620.pdf

Voas, RB. Emerging technologies for controlling the drunk driver. In: Lawrence, MD.; Nortum, JR.; Zimring, FE., editors. Social control of the drunk driver. Chicago, IL: University of Chicago Press; 1988. p. 321-370.

Voas RB. A new look at NHTSA's evaluation of the 1984 Charlottesville Sobriety Checkpoint Program: Implications for current checkpoint Issues. Traffic Inj Prev. 2008; 9:22-30. [PubMed: 18338291]

Voas, RB.; Lacey, JH. Drunk driving enforcement, adjudication, and sanctions in the United States. In: Wilson, RJ.; Mann, RE., editors. Drinking and driving: Advances in research and prevention. New York: The Guilford Press; 1990. p. 116-158.

Voas RB, Lacey JH, Fell JC. The PASpoint system - passive sensors at mini-checkpoints: Bringing Australia's random breath-test system to the United States. Transportation Research Circular. 2005; E-C072:45-53.

Voas RB, Romano E, Peck R. Validity of the passive sensor for identifying high BAC drivers at the crash scene. J Stud Alcohol. 2006; 67:714-721. [PubMed: 16847540]

Wagenaar A, Maldonado-Molina M, Ma L, Tobler A, Komro K. Effects of legal BAC limits on fatal crash involvement: Analyses of 28 states from 1976 through 2002. J Saf Res. 2007; 38:493-499.

Wagenaar AC, Maldonado-Molina MM. Effects of drivers' license suspension policies on alcoholrelated crash involvement: Long-term follow-up in forty-six states. Alcohol Clin Exp Res. 2007; 31:1399-1406. [PubMed: 17559543]

Watson, B. Trends in impaired driving in Australia in 2010. T2010 Conference; 22-26 August 2010; Oslo, Norway: International Conference on Alcohol, Drugs and Traffic Safety (ICADTS); 2010. Book of Abstracts

Wells, JK.; Greene, MA.; Foss, RD.; Ferguson, SA.; Williams, AF. Drivers with high BACs missed at sobriety checkpoints. Arlington, VA: Insurance Institute for Highway Safety; 1996.

Widmark, EMP. Principles and applications of medicolegal alcohol determination. Davis, CA: Biomedical Publications; 1932.

Zador, P.; Krawchuk, S.; Moore, B. Drinking and driving trips, stops by police, and arrests: Analyses of the 1995 national survey of drinking and driving attitudes and behavior. Washington, DC: U.S. Department of Transportation, National Highway Traffic Safety Administration; 2000. DOT HS 809184 
Zaloshnja E, Miller TR. Cost of crashes related to road conditions, United States, 2006. Ann Adv Automot Med. 2009; 53:141-153. [PubMed: 20184840]

Zwicker, TJ.; Hedlund, J.; Northrup, VS. Breath Test Refusals in DWI Enforcement: An Interim Report. Washington, DC: U.S. Department of Transportation, National Highway Traffic Safety Administration; 2005. DOT HS 809876 


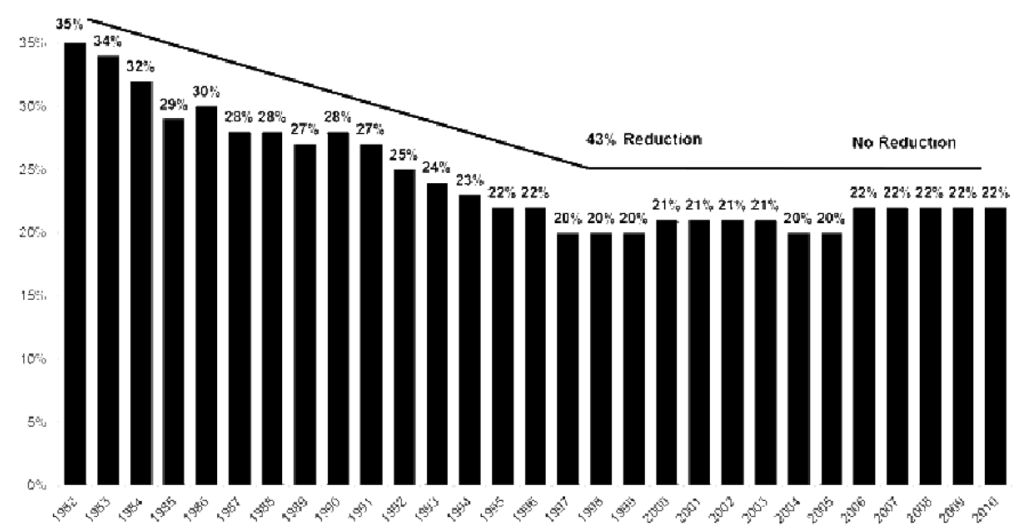

Figure 1. Proportion of All Drivers Involved in Fatal Crashes Estimated to Have Been Legally Intoxicated (BAC $\geq 08$ ), 1982-2010

Source: Fatality Analysis Reporting System (FARS), NHTSA, 2012 


\begin{tabular}{|c|c|}
\hline 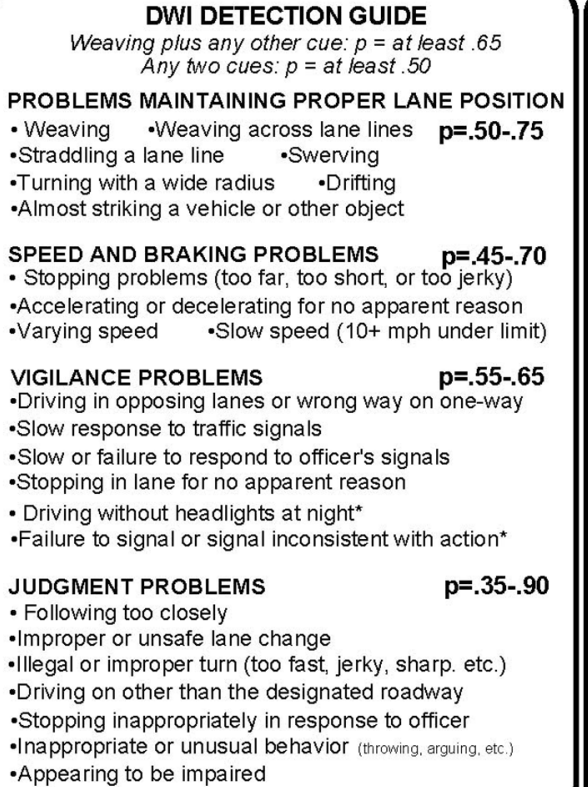 & $\begin{array}{l}\text { POST STOP CUES } \\
\text { - Difficulty with motor vehicle controls } \\
\text { - Difficulty exiting the vehicle } \\
\text { - Fumbling with driver's license or registration } \\
\text { - Repeating questions or comments } \\
\text { - Swaying, unsteady, or balance problems } \\
\text { - Leaning on the vehicle or other object } \\
\text { - Slurred speech } \\
\text { - Slow to respond to officer/officer must repeat } \\
\text { - Provides incorrect information, changes answers } \\
\text { - Odor of alcoholic beverage from the driver }\end{array}$ \\
\hline
\end{tabular}

Figure 2. DWI Driver Detection Guide

Source: Stuster 1997 


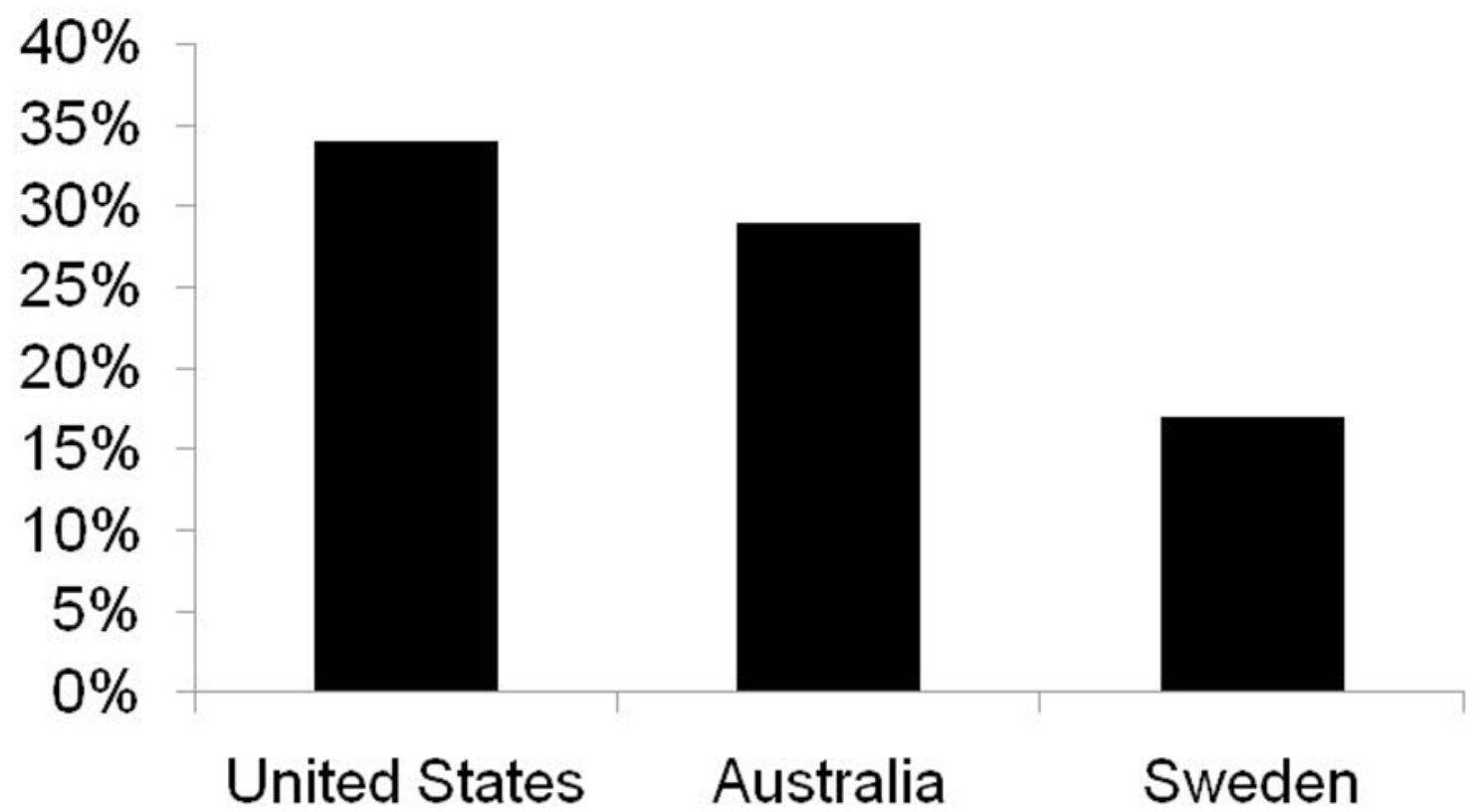

Figure 3. Proportion of Fatally Injured Drivers with BACs $\geq .05 \mathrm{~g} / \mathrm{dL}$ in 2006

Sources: United States, FARS, NHTSA 2012; Australia, Watson 2010; and Sweden, Jones 2010

Note: The illegal BAC limit for driving is $.08 \mathrm{~g} / \mathrm{dL}$ in the United States, $.05 \mathrm{~g} / \mathrm{dL}$ in Australia, and $.02 \mathrm{~g} / \mathrm{dL}$ in Sweden 
Table 1

The Three Steps in the DWI Apprehension and Arrest Process

\begin{tabular}{|c|c|c|c|c|}
\hline & Australia & Sweden & Britain & U.S. \\
\hline \multicolumn{5}{|l|}{ Step 1. Select Vehicle } \\
\hline a. At random & $\mathrm{x}$ & & & \\
\hline b. At checkpoints & & $\mathrm{X}$ & & \\
\hline c. Based on impaired driving & & & $\mathrm{X}$ & $\mathrm{X}$ \\
\hline d. Based on traffic offense & & & $\mathrm{X}$ & \\
\hline \multicolumn{5}{|l|}{ Step 2. Roadside Interview } \\
\hline a. Mandatory breath test & $\mathrm{X}$ & $\mathrm{X}$ & $\mathrm{X}$ & \\
\hline b. Field sobriety test & & & & $\mathrm{x}$ \\
\hline \multicolumn{5}{|l|}{ Step 3. At the Police Station } \\
\hline a. Mandatory breath test & $\mathrm{x}$ & $\mathrm{x}$ & $\mathrm{x}$ & \\
\hline b. Voluntary breath test/license penalty & & & & $\mathrm{x}$ \\
\hline
\end{tabular}


Table 2

Police Detection of Drivers with BACs $\geq .10 \mathrm{~g} / \mathrm{dL}$ : With and Without the Use of Passive Alcohol Sensors (PAS)

\begin{tabular}{lcc}
\hline & \multicolumn{2}{c}{ Percentage detected } \\
\cline { 2 - 3 } & Without PAS & With PAS \\
\hline Sobriety checkpoints: & & \\
Charlottesville, VA & 45 & 68 \\
Fairfax, VA & 55 & 71 \\
Routine patrol: & & \\
Columbus, OH & 69 & 77 \\
Special DUI patrol: & & \\
Chattanooga, TN & 88 & 94 \\
\hline
\end{tabular}

Source: Ferguson et al. 1995; Wells et al. 1996 